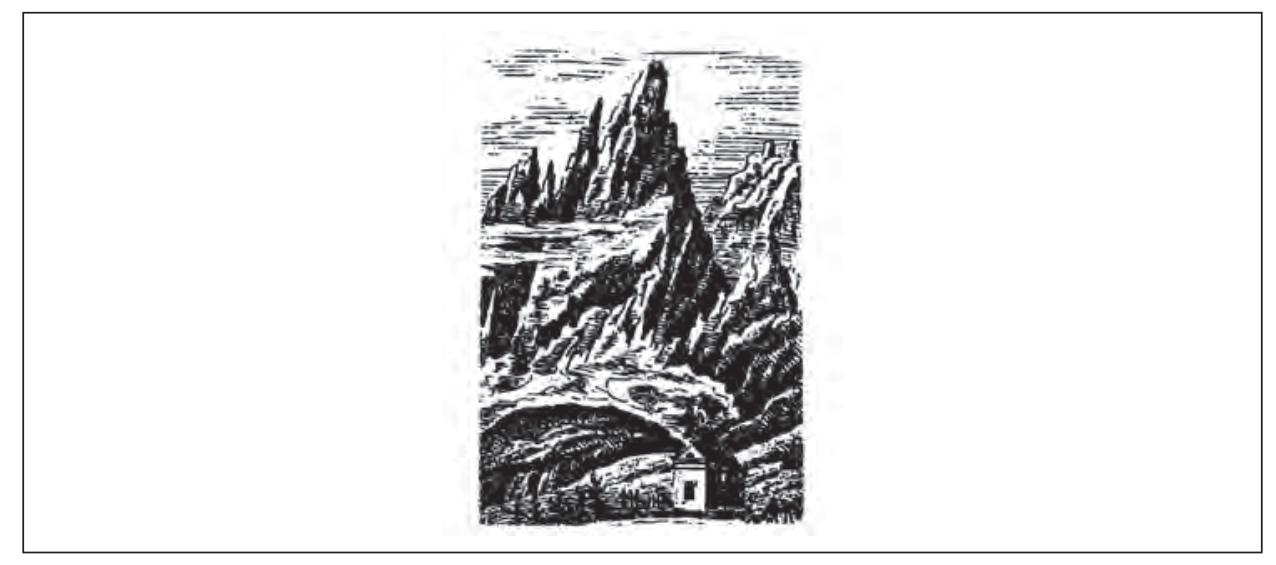

\author{
Jan Pacholski \\ ORCID: 0000-0001-8108-678X \\ Uniwersytet Wroctawski \\ jan.pacholski@uwr.edu.pl
}

https://doi.org/10.19195/2084-4107.13.27

\title{
„Nasze śląskie Alpy”, a skały „jak ruiny Palmiry czy Persepolis" - albo różne optyki karkonoskich podróżopisarzy
}

Słowa-klucze: Karkonosze, Śląsk, Prusy, Czechy, Alpy, Szwajcaria, polihistorzy, badacze, oświecenie, podróżopisarstwo

Keywords: Giant Mountains (Karkonosze), Silesia, Prussia, Bohemia, Alps, Switzerland, polymaths, scholars, Enlightenment, travel writing

\section{"Our Silesian Alps", rocks "like the ruins of Palmira or Persepolis" — or various perspectives of Giant Mountains travel writers}

\section{Summary}

The present article focuses on eighteenth-century German-language descriptions of the Giant Mountains and Izera Mountains included in selected eighteenth-century accounts of trips to the high- 
est mountains of Silesia and Bohemia by travellers from various German-speaking countries. The analysed fragments refer primarily to sites on the Silesian side of these mountain ranges, although the Bohemian part is mentioned in one case.

Differing in terms of their countries of origin, the authors of these works - who included Silesians, a German from Bohemia as well as a man from Berlin and a man from Saxony - liked to refer in their accounts to well-known Swiss models, primarily to the poetic works of Albrecht von Haller and scholarly works of Johann Jakob Scheuchzer, comparing the Giant Mountains to the Alps and using in their descriptions of nature metaphors inspired by the famous Swiss authors, whose oeuvres were quite popular across the entire civilised Europe.

The present article provides a detailed analysis of the descriptions of the various natural sites and phenomena, in which the authors use the vocabulary of the history of art and culture, comparing, for example, the view of valleys seen from a mountain top to miniature painting, a waterfall to a performance and music, and rock formations to architectural objects and ancient ruins.

Trudno powiedzieć coś nowego na temat epokowego dzieła Albrechta von Hallera, jakim bez wątpienia jest jego poemat Die Alpen (Alpy), opublikowany w 1732 roku w zbiorze Versuch Schweizerischer Gedichte [Próba wierszy szwajcarskich]; pierwotna wersja tego utworu, później wielokrotnie rozszerzanego i rewidowanego, została ukończona w lipcu 1729 roku$^{1}$ jako pokłosie wielkiej podróży przez ojczyste góry², którą słynny berneńczyk odbył ze swym nie mniej znanym zuryskim przyjacielem, przyszłym profesorem Johannesem Gessnerem ${ }^{3}$. Dlatego też, nie wdając się w próby proponowania nowych czy też przedstawiania istniejących już interpretacji Alp, przytoczmy na wstępie niniejszego szkicu nasz przekład pierwszej decymy, otwierającej ostateczną wersję dzieła Helwety

${ }^{1}$ Por. obszerna przedmowa do pomnikowego wydania wierszy berneńczyka, paginowana osobno cyframi rzymskimi - L. Hirzel, Hallers Leben und Dichtungen [Życie i poematy Hallera], [w:] A. von Haller, Gedichte, red. L. Hirzel, Frauenfeld 1882, s. LXXIII.

${ }^{2}$ Podróż niespełna dwudziestoletniego Albrechta von Hallera i o niecały rok młodszego Johannesa Gessnera, której głównym celem były badania botaniczne, rozpoczęła się 7 lipca 1728 roku; dwaj przyjaciele ruszyli z Bazylei, by przez góry i głębokie doliny Jury dotrzeć do miasta Biel/Bienne. Stamtąd, wędrując równolegle do pasma Jury, udali się do miasta Orbe, a później przez Lozannę do Genewy. Dalej, przemierzając kantony Waadt/Vaud i Wallis/Valais, podróżni osiągnęli przełęcz Gemmi i zagłębili się w góry Oberlandu Berneńskiego. Opuszczając kanton berneński na przełęczy Jochpaß, wędrowcy udali się do Engelbergu i Stans; następnie, omijając Jezioro Czterech Kantonów (Vierwaldstättersee), przez Lucernę osiągnęli Zurych, gdzie Gessner pozostał na jakiś czas, powracając do swoich innych zajęć. Haller zatrzymał się w owym mieście na cztery dni (5-8 sierpnia), w czasie których między innymi spotkał się ze słynnym tamtejszym przyrodoznawcą Johannem Jacobem Scheuchzerem i obejrzał jego zbiory. Wędrując już samotnie, berneńczyk udał się przez Baden, Königsfelden i Langenthal do Berna, które osiągnął pod koniec miesiąca. Dwaj przyjaciele ponownie spotkali się dopiero późną jesienią tegoż roku w Bazylei. Jeżeli przyjąć ustalenia Hirzela („Reise von zweihundertsechzehn Schweizerstunden” - ibidem, s. LXI), posługującego się starą szwajcarską jednostką odległości zwaną „Wegstunde” (,godzina drogi” $=16000$ stóp $=4,8 \mathrm{~km}$ ), dystans pokonany przez Hallera wynosił nieco ponad tysiąc kilometrów $(216 \times 4,8=1036,8 \mathrm{~km})$. Na temat opisanej tu marszruty zob. ibidem, s. LX-LXI i LXV (w podrozdziale Die Alpenreise. Hallers neue philosophische Dichtung [Podróż alpejska. Nowe wiersze filozoficzne Hallera], s. LX-LXXX).

3 Por. A. von Haller, Die Alpen (1729), [w:] idem, Gedichte..., s. 20. 
Rozważ to, śmiertelniku ${ }^{4}$, jak byt poprawić swój,

I użyj zmyślnych sztuk, darów natury też;

Ożyw więc kwiecie łąk, niech tryska w górę zdrój,

A skał rozkutych kształt miarą Koryntu mierz;

Na marmurowe ściany perską tapetę daj,

Trufle $^{5}$ na złocie jedz, perły w szmaragdzie pij;

Zaśnij przy lutni grze, przy trąbach rankiem staj;

$\mathrm{Z}$ drogi swej skały zmieć, na łowy las zamknij;

Zechce życzenia twe ziścić pazerny los,

To w szczęściu biednyś wciąż, nędznyś, choć pełny trzos ${ }^{6}$.

${ }^{4}$ Aby zmieścić się mniej więcej w liczbie sylab narzuconej formą wersu — w oryginale aleksandrynu, thumacząc niniejszy fragment, zdecydowano się na zamianę trybu rozkazującego 2. osoby liczby mnogiej na takiż tryb 2 . osoby liczby pojedynczej.

5 W oryginale wspomniane jest ,gniazdo Tonkinu” („Tunkins Nest”) — autor ma na myśli tak zwane jaskółcze gniazda, to jest dalekowschodnią (indochińską) potrawę przyrządzaną z jadalnych części miejsc lęgowych salangan, ptaków z rodziny jerzykowatych, niekiedy mylnie utożsamianych z jaskółkami. Różne gatunki salangan konstruują swoje „domostwa”, używając do tego celu wydzieliny z własnych gruczołów ślinowych, czasem też mieszając ją z innymi substancjami. Niezwykle cenne surowce stanowiące bazę dania, o którym pisze Haller, wywodzą się — zdaniem późniejszych niemieckich oraz francuskich wydawców i redaktorów dzieł berneńczyka - z Tonkinu, historycznej krainy obejmującej północną część dorzecza Sông Hồng na terenie dzisiejszego Wietnamu, a ściślej — z wysp leżących w Zatoce Tonkińskiej, należącej do Morza Południowochińskiego: „Słynne ptasie gniazda, w Indiach powszechnie uchodzące za przysmak, które widuje się też na najwykwintniejszych stołach Europy, znajdywane są na wyspach u wybrzeży Tonkinu" („Die berühmten Vogelnester, die in Indien unter den Leckerbissen ganz bekannt sind, und die man auch in Europa auf vornehmen Tischen sieht, findet man auf einigen Inseln am Ufer von Tunkin") — A. von Haller, Die Alpen (1729)..., s. 20-21, przyp. do w. 6; jeśli nie podano inaczej, przeł. J.P. $\mathrm{W}$ niniejszym thumaczeniu, z przyczyn podobnych do nazwanych w poprzednim przypisie, ową egzotyczną potrawę azjatycką postanowiono zastąpić zdecydowanie bliższymi nam kulturowo, ale przecież wcale nie mniej wykwintnymi truflami; wydaje się, że nie zmienia to wydźwięku słów Hallera, a nieco poprawia zrozumiałość przekładu i — przede wszystkim — umożliwia jakiekolwiek zmieszczenie się w metrum.

${ }^{6}$ A. von Haller, Die Alpen (1729), [w:] idem, Versuch Schweizerischer Gedichte, Göttingen ${ }^{4} 1748$, s. 30, w. 1-10: „Versuchts, ihr Sterbliche, macht euren Zustand besser, / Braucht was die Kunst erfand, und die Natur uns gab; / Belebt die Blumen-Flur mit steigendem Gewässer, / Theilt nach Korinths Gesetz gehaune Felsen ab; / Umhängt die Marmor-Wand mit Persischen Tapeten, / Speißt Tunkins Nest aus Gold, trinkt Perlen aus Smaragd; / Schlaft ein beym Saitenspiel, erwachet bey Trompeten; / Räumt Klippen aus der Bahn, schließt Länder ein zur Jagd; / Wird schon, was ihr gewünscht, das Schicksal unterschreiben, / Ihr werdet arm im Glück, im Reichthum elend bleiben". Niniejsza decyma została dopisana przez autora dopiero później, nie ma jej w pierwszym wydaniu utworu z 1732 roku — por. A. von Haller, Die Alpen (1729), [w:] idem, Gedichte..., s. 20. W kolejnych wydaniach Haller dokonywał korekt i modyfikacji tej strofy; na potrzeby niniejszego przyczynku, aby w miarę precyzyjnie ukazać zawarte w tym fragmencie treści i sformułowania, zdecydowano się dokonać własnego przekładu, opierając się na wskazanym czwartym wydaniu zbioru wierszy berneńczyka, które ukazało się w Getyndze nakładem wydawnictwa Abrahama Vandenhoecka. Wszystkie fragmenty publikacji niemieckojęzycznych, które w niniejszym szkicu zacytowane zostały w przekładzie na język polski, w przypisach dla porównania umieszczono w brzmieniu oryginalnym, nie zmieniając ich pierwotnej ortografii, nierzadko znacznie odbiegającej od dzisiejszej. 
W zacytowanym fragmencie wymienione zostały liczne przedmioty będące znamionami czy to luksusu - szampan (,perły”) pity z kielichów ze szlachetnego szkła kryształowego (,w szmaragdzie") i trufle (w oryginale tak zwane jaskółcze gniazda) spożywane ze złotych naczyń, czy to wysokiej kultury materialnej architektura trzymająca się porządku korynckiego — bądź niematerialnej — trąby i lutnie (w oryginale struny) reprezentujące muzykę. Owe symbolicznie ukazane elementy przypisane są nie tylko bogactwu jako takiemu, lecz także — jeśli nie przede wszystkim - możnym tego świata ${ }^{7}$, warstwom panującym ${ }^{8}$, którym w dalszej części poematu en passant wystawiona zostaje najgorsza cenzura.

Abstrahując od kwestii nastawienia Hallera do tematów stricte politycznych, pozostaje nam skonstatować, że przy okazji konstruowania obrazów mających ukazać, czasami - jak się zdaje - par force, opozycję natury wobec kultury, tej ostatniej „obrywa się” nieco więcej, niżby na to faktycznie zasługiwała. W Alpach zdyskredytowane zostają bowiem nie tylko przedmioty zbytku, ale też wytwory i przejawy sztuki wszelakiej — z ars amandi ${ }^{9}$ włącznie. Wobec takiego stanu rzeczy zaskakiwać może, że liczni autorzy relacji z podróży górskich z drugiej połowy XVIII wieku, w wielu miejscach nader ochoczo — ba, nierzadko natrętnie! — powołujący się na słynnego berneńczyka, w swoich opisach przyrody nie próbują podążając za Hallerem — poszukiwać dla jej przedstawienia nowego, suwerennego języka, a odwołują się w swym obrazowaniu do słownictwa z dziedziny sztuki i kultury. Deklarując z jednej strony swe uwielbienie dla wartości przedstawionych między innymi w poemacie Alpy, z drugiej odnoszą się do sfery przez tenże wiersz zdyskredytowanej - opisując naturę, odwołują się do słownictwa i pojęć nazywających zjawiska z obszaru kultury. Powodując u dzisiejszego czytelnika niemały dysonans poznawczy, zdają się pozostawać w niebezpiecznym szpagacie, który przy odrobinie złej woli można by określić mianem hipokryzji.

Przedstawiwszy nader ogólnikowo zjawisko zaobserwowane w trakcie wieloletnich badań nad niemieckojęzycznym podróżopisarstwem drugiej połowy XVIII wieku, głównie dotyczącym Karkonoszy i Gór Izerskich (traktowanych w owym czasie jako całość), przytoczmy teraz konkretne przykłady takich strategii idealizacyjnych, których istotą jest przyrównanie obserwowanych obiektów i zjawisk przyrodniczych do dzieł sztuki czy szerzej - wytworów kultury.

Powstające po wojnach śląskich (1740-1742, 1744-1745 i 1756-1763), a zwła-szcza po ostatniej z nich - wojnie siedmioletniej, relacje z podróży po obszarze zaanektowanym przez Fryderyka II Wielkiego siłą rzeczy zawierały w sobie liczne opisy gór Śląska, a także ziemi kłodzkiej. Dająca się zaobserwować wyraźna koncentracja podróżopisarzy na tematyce górskiej miała przynajmniej dwie przyczyny. Pierwszą z nich, dotyczącą zwłaszcza autorów pochodzących spoza terenu późniejszej pruskiej prowincji śląskiej, było poniekąd naturalne zainteresowanie ludzi nizin niespotykanym w ojczyźnie zjawiskiem, jakim jawiły się im góry — nawet tak

\footnotetext{
7 Por. A. von Haller, Die Alpen (1729), [w:] idem, Gedichte..., s. 21, w. 11-20; s. 22, w. 43-50.

8 Por. ibidem, s. 26, w. 126-130, 139-140; s. 27, w. 149-150.

9 Por. ibidem, s. 27, w. 157.
} 
niewysokie jak Karkonosze (podobne zjawisko dotyczy w owym czasie Harzu). Drugim, nie mniej ważnym, powodem ówczesnego zwrotu ku górom były docierające do przedstawicieli pruskiego oświecenia wzorce ze Szwajcarii, idealizowanej w kręgach elit intelektualnych jako kraj postępu, równości i tolerancji — zwłaszcza religijnej. Wspomniane na wstępie Alpy Albrechta von Hallera, już wtedy bardzo intensywnie recypowane w całym niemieckim obszarze językowym, stanowiły w tym kontekście niezwykle ważny element.

Dobrym przykładem dzieła wpisującego się w ów nurt jest publikacja, wydana w 1784 roku nakładem berlińskiej oficyny Augusta Myliusa, zatytułowana Reise von Berlin über Breslau nach dem schlesischen Gebirge im Sommer 1783 von J.E.T. [Podróż J.E.T.-a z Berlina przez Wrocław ku śląskim górom latem 1783 roku]; skrytym za inicjałem autorem owej relacji z podróży był ewangelicki duchowny Jakob Elias Troschel z Berlina, znany przede wszystkim ze swych prac teologicznych. Oprócz opisu stołecznego Wrocławia oraz kilku innych miast Dolnego Śląska utwór ten zawiera nie tylko wiele uwag na temat życia duchowego mieszkańców odwiedzanych terenów, co — zważywszy na osobę podróżopisarza — wydaje się zupełnie logiczne, lecz także liczne opisy górskiego krajobrazu; notabene nie tylko ze śląskiej części Sudetów, ale też z przygranicznego obszaru Czech, o czym jeszcze będzie dane nam wspomnieć.

Oprócz powstających w owym czasie prac pisanych przez przybyszów z ,lasków i piasków" Brandenburgii warto odnotować również utwory, które wyszły spod pióra proprusko nastawionych Ślązaków, jak choćby ciekawe - zwłaszcza ze względu na nader niestandardową marszrutę - sprawozdanie bolesławieckiego duchownego ewangelickiego Erdmanna Friedricha Buquoia, opublikowane pod tytułem Beschreibung meiner Reise durch einen Theil des schlesischen Gebirge, in etlichen Briefen an den Herrn Insp. Woltersdorff [Opis mej podróży przez część śląskich gór, w kilku listach do pana inspektora Woltersdorffa] jako dodatek do czasopisma „Bunzlauischen Monathschrift” = „Bunzlauische Monathschrift zum Nutzen und Vergnügen” [„,Miesięcznik Bolesławiecki” = „Miesięcznik Bolesławiecki dla Pożytku i Rozrywki”] w 1783 roku, a zatem dokładnie w czasie podróży berlińskiego teologa Troschela.

Zdecydowanie najciekawsza publikacja dająca się umieścić w tejże grupie, a więc łącząca opis podróży przez cały kraj, względnie — jak się okaże — różne kraje, z wyrywkowym przedstawieniem odwiedzonych obszarów górskich, wyszła spod pióra autora pochodzącego z Quedlinburga u podnóża Harzu, znanego niemieckiego pedagoga i pioniera wychowania fizycznego Johanna Christopha Friedricha GutsMuthsa, z wykształcenia również teologa ewangelickiego. Jego dzieło, opublikowane anonimowo we wrocławskiej oficynie Korna w 1799 roku, jest najobszerniejszą z przedstawionych tutaj relacji z podróży — liczy 260 stron; zarówno sam tytuł publikacji, jak i przede wszystkim pokonana przez autora marszruta, mogąca się śmiało mierzyć z drogą Hallera i Gessnera, są imponujące. Utwór zatytułowany jest Meine Reise im deutschen Vaterlande, aus Thüringen ins Riesengebürge zu den Elbquellen und durch Böhmen ins Erzgebürge; über Erfurt, Leipzig, Dresden, Bautzen, Görlitz, Bunzlau, Warmbrunn, Hirschberg, Arnau, 
Turnau, Prag und Töplitz bis Freyberg [Moja podróż po ojczyźnie niemieckiej, z Turyngii w Karkonosze do źródeł Łaby i przez Czechy w Rudawy; przez Erfurt, Lipsk, Drezno, Budziszyn, Zgorzelec, Bolesławiec, Cieplice Śląskie-Zdrój, Jelenią Górę, Hostinné, Turnov, Pragę i Teplice aż do Fryburga Saskiego] — na podstawie tego tytułu łatwo wyobrazić sobie trasę podróży - i z pewnością zasługuje na bliższe przedstawienie ${ }^{10}$, jednak $\mathrm{z}$ wiadomych przyczyn skoncentrujemy się tutaj jedynie na kilku wybranych aspektach.

Pierwszym przykładem zastosowania w opisie krajobrazu języka kojarzonego raczej ze słownictwem używanym przez historyków sztuki jest przyrównanie rozległej panoramy obserwowanej z górskiego szczytu lub z innego wywyższonego miejsca do malowidła. I choć tego rodzaju zabieg można znaleźć zarówno w dziele Troschela, jak i w listach Buquoia, dla zilustrowania tego zjawiska zdecydowaliśmy się przywołać wypowiedź GutsMuthsa: „Zamieszkały świat leży poniżej w niewyraźnej głębi, niczym miniaturowy obraz [wyr. - J.P.], który oglądany z oddali ukazuje się oczom rozmyty i nieostry" "11. Owa nader krótka uwaga, dokonana niejako z perspektywy lotu ptaka, prowadzi nas ku dalszym opisom, które można znaleźć w dziele podróżopisarza i pedagoga z Quedlinburga. Na szczególną uwagę zasługuje plastyczny opis Wodospadu Szklarki, w którym autor pisze o „malowniczej dłoni natury” jako o instancji kształtującej przedstawiony w tym miejscu element krajobrazu:

Tu, śród gęstej świerczyny, w wąskiej dolinie, malowni c za dłoń n a tu ry [wyr. - J.P.] postawiła wysoko w przestworza skalny uskok z granitu, szorstki i dziki, a piękny, urozmaicony tysiącem załomów i wgłębień. [...] Zakrzywiła [owa „malownicza dłoń natury” — J.P.] ten skalny a mfiteatr [wyr. - J.P.], tworząc zakątek czy też zatokę, w której rzeka, oglądana z dołu, zda się wypływać spośród korzeni świerków z ogłuszającym łoskotem, tworząc jeden jedyny łuk i spadając z wysokości 50 stóp $^{12}$.

10 Zainteresowanych osobą i twórczością GutsMuthsa pozwalamy sobie odesłać do artykułu autora niniejszego przyczynku, opublikowanego pod koniec 2013 roku w podwójnym numerze czasopisma „Silesia Nova” (nr 3-4), zatytułowanego Auf GutsMuths’ Spuren im Riesengebirge - fast eine Wanderung ([Śladami GutsMuthsa w Karkonoszach — taka prawie wędrówka], s. 178-218).

11 J.Ch.F. GutsMuths, Meine Reise im deutschen Vaterlande, aus Thüringen ins Riesengebürge zu den Elbquellen und durch Böhmen ins Erzgebürge; über Erfurt, Leipzig, Dresden, Bautzen, Görlitz, Bunzlau, Warmbrunn, Hirschberg, Arnau, Turnau, Prag und Töplitz bis Freyberg, Breslau-HirschbergLissa in Südpreußen 1799, s. 137: „Die bewohnte Welt liegt dort unten undeutlich in der Tiefe, wie ein Miniatur-Gemählde, das aus zu großer Entfernung dem Auge unkenntlich und verwischt erscheint".

12 Ibidem, s. 111-112: „Hier hat die Natur, mitten im dichten Fichtenwalde, in einem schmalen Thale, mit malerischer Hand einen Felsenabsatz von Granit hoch in die Luft gemauert, rauh und wild, durch tausend Ecken und Vertiefungen mannichfaltig und schön. [...] Dies freie Felsentheater krümmte sie [jene »malerische Hand der Natur«], und bildete so einen Winkel, oder Busen, in welchem der Fluß, der von unten betrachtet, oben aus den Wurzeln der Fichten zu kommen scheint, donnernd, in einem einzigen Bogen, $50 \mathrm{Fuß}$ hoch herabstürzt”. 


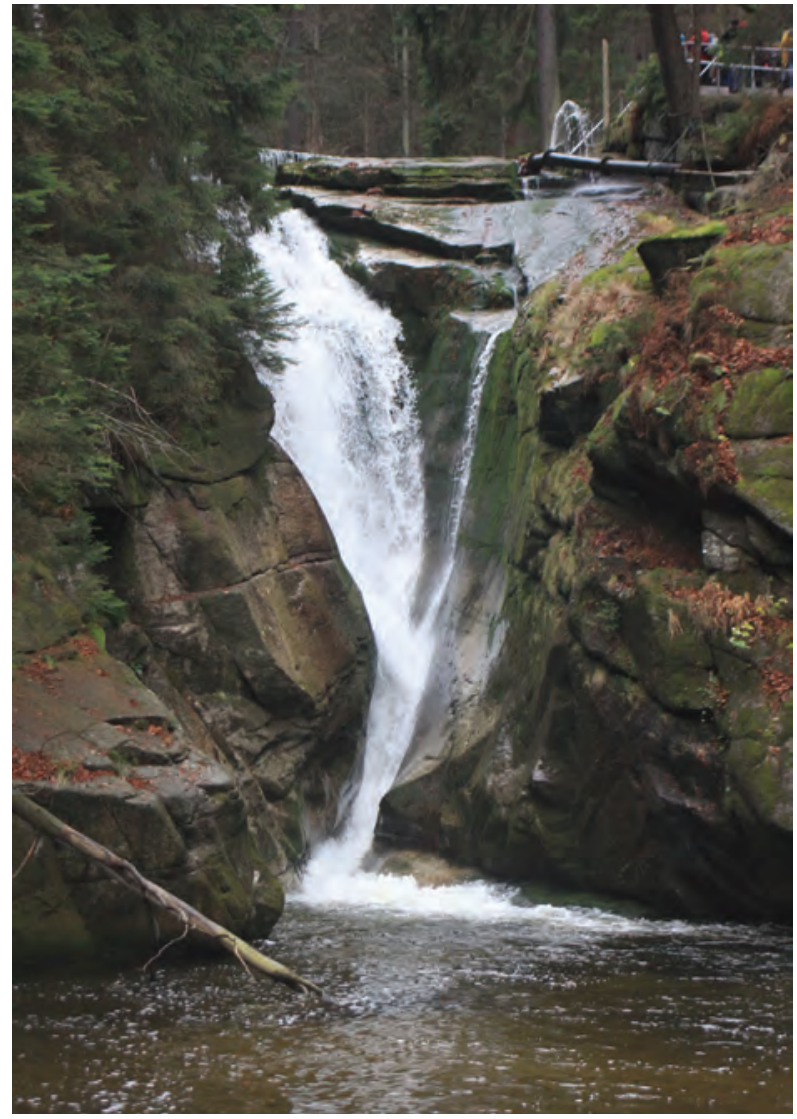

1. Wodospad Szklarki nieopodal Szklarskiej Poręby w dolnośląskich Karkonoszach, fot. Jan Pacholski (listopad 2013)

I choć w przytoczonym fragmencie to właśnie natura ukazana jest wprost jako siła, która wytworzyła opisywany obiekt, to jednak zostają jej przypisane cechy ludzkie; co więcej, są to przymioty właściwe działającemu w zgodzie z zasadami sztuki artyście, natomiast efekt końcowy owego kształtowania przestrzeni zostaje przyrównany do obiektu architektonicznego, jakim jest amfiteatr. Owo porównanie skał do budowli, notabene jednoznacznie kojarzonych z antykiem, powtarzać się będzie także u kilku innych autorów; co jednak wyróżnia opis pióra GutsMuthsa, to umieszczenie w owym ,skalnym amfiteatrze" takich niematerialnych elementów jak „spektakl” i „muzyka”, czyli właściwych temu miejscu komplementarnych „sztuk performatywnych". Dopiero w dalszej części opisu pojawia się grota, podmiotem zaś, który ją wyżłobił, nie jest już jakaś „,malownicza dłoń natury”, a po prostu rzeka:

Długo siedziałem na zaokrąglonej stożkowatej skale, upojony zachwytem; przyglądałem się śmiałemu s p e k tak low i [wyr. - J.P.] i wsłuchiwałem się w grzmiącą m u z y k ę [wyr. - J.P.] wodospadu, brzmiącą w dolinie i odbijającą się od skały do skały, aż na lewym brzegu odkry- 
łem grotę, która wywabiła mnie z mego miejsca. Pospieszyłem więc, omijając olbrzymi blok skalny, i znalazłem śród granitu wielką pieczarę, którą, na przestrzeni wielu chyba stuleci, wyżłobiła rzeka ${ }^{13}$.

Prócz publikacji powstałych w celu zrelacjonowania podróży przez większy obszar Śląska oraz ewentualnie sąsiednich krain, zawierających opisy terenów górskich, w drugiej połowie XVIII wieku, na fali rozwoju przyrodoznawstwa, publikowano też dzieła specjalistyczne, poświęcone jedynie poszczególnym pasmom przede wszystkim Karkonoszom. Za jedną z najważniejszych prac tego typu można uznać Reisen nach dem Riesengebirge [Podróże ku Karkonoszom] pióra Johanna Tobiasa Volkmara, niegdysiejszego proboszcza ewangelickiego z podkarkonoskich Piechowic, późniejszego kaznodziei kościoła św. Elżbiety we Wrocławiu. Utwór ten ukazał się w formie książkowej ${ }^{14} \mathrm{w} 1777$ roku w znanej bolesławieckiej oficynie Drukarnia Sierocińca (Buchdruckerey des Waisenhauses). Piechowicki duchowny wzorował się w swym przyrodoznawczym opisie Karkonoszy na pracach kolejnego prominentnego Szwajcara, Johanna Jacoba Scheuchzera ${ }^{15}$, a zwłaszcza na jego opublikowanym w 1716 roku w Zurychu monumentalnym dziele Helvetice Historia Naturalis Oder Natur-Historie Des Schweitzerlandes [Historia naturalna Helwecji].

I choć w swym opisie najwyższych gór Śląska nasz rodzimy duszpasterz odnosi się także do Alp Hallera, przytaczając nawet kilka wersów poematu, to przedstawiając skały, wpada w ten sam dukt co GutsMuths ${ }^{16}$. Dzieje się tak na przykład, gdy omawia formację Pielgrzymów, które w przytoczonym tu przekładzie nazwano „Trójkamieniem”, pozostając tym samym w zgodzie z niemiecką nazwą „Dreisteine”:

Zwie się je Tr ó j k a m i e n i e m [wyr. oryg.], gdyż z dali tylko zdają się trzema osobnymi skałami. Podążcie za mną ku ich miejscu, a nie tylko uznacie je godnymi uwagi, lecz przekonacie się też, że jest ich dużo więcej. Najpierw stoi tu w półokręgu ściana, której olbrzymie skalne bloki tak równo na sobie leżą, jakby wymierzył je architekt i ustawił je w zgodzie z zasadami sztuki, albo lepiej jeszcze, jakby to architekt tu właśnie pobierał nauki, z tego brał wzór i wedle tego ustanawiał swe reguły. Cóż za niebotyczne wysokości! Jakież to przemyślnie nawarstwione kamienne

13 Ibidem, s. 112: „Lange saß ich da auf einem abgerundeten kegelförmigen Felsen, trunken von Entzücken; betrachtete das kühne Schauspiel und horchte der donnernden Musik des Falles, die im Thale von Felsen zu Felsen hallt, bis ich am linken Ufer eine Felsengrotte entdeckte, die mich von meinem Sitze lockte. Ich eilte um einen ungeheuren Felsenblock herum, kletterte hinab, und fand im Granit eine große Höhle, die der Fluß, vielleicht in einem Zeitraum von vielen Jahrhunderten, ausgewaschen hat".

14 Wcześniej, w 1760 roku, poszczególne części dzieła ukazywały się w Jeleniej Górze w cotygodniowych odcinkach pod zbiorczym tytułem Beruhigungen des Herzens bey äuserlichen Weltunruhen durch allerley nützliche und gottselige Betrachtungen [Serca ukojenia w czas niepokoju na świecie przez wszelakie rozważania pożyteczne a nabożne], nawiązującym do trwającej wówczas wojny siedmioletniej (1756-1763).

15 Por. przyp. 2.

16 Dla porządku należy dodać, że dzieło quedlinburczyka powstało później. 


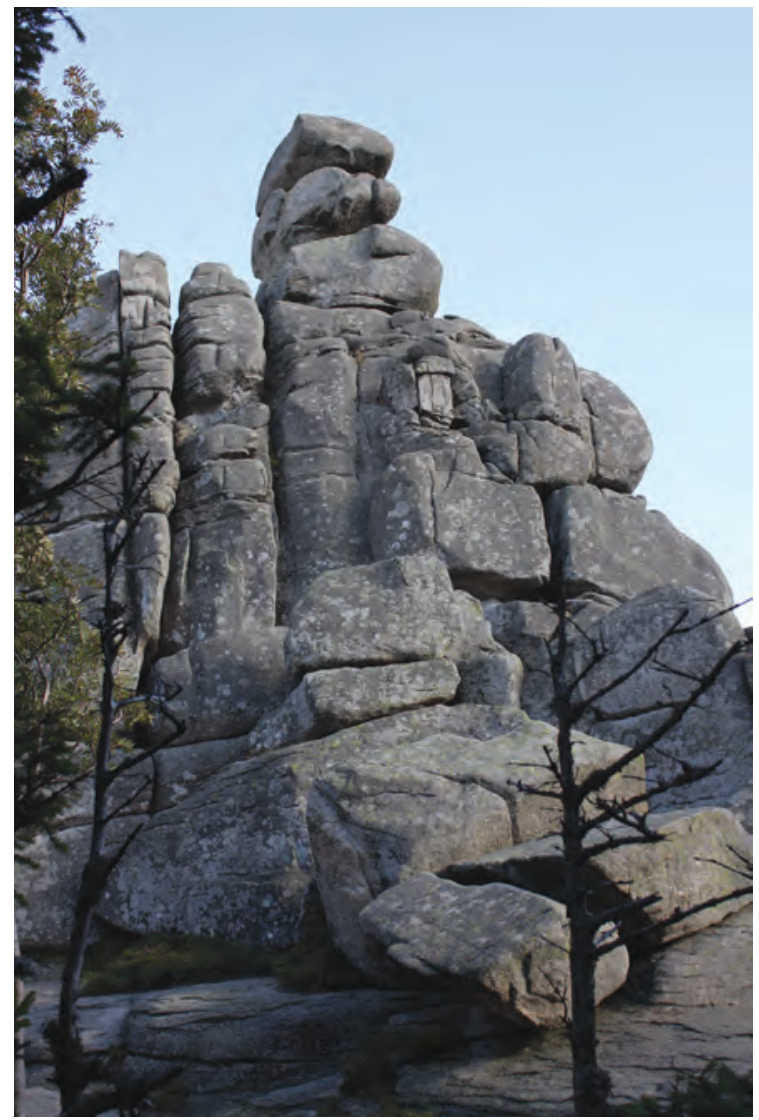

2. Jedna ze skał tworzących formację Pielgrzymów w dolnośląskich Karkonoszach, fot. Jan Pacholski (wrzesień 2015)

gzymsy! Jakież to figury, niczym wznoszące się ku górze wieże, niczym wazy z kwiatami i inny detal architektoniczny! I któż, wobec wielkiej rozmaitości kształtów kamieni, zdoła to wszystko opisać? A cała ściana długa jest na ponad 100 kroków $^{17}$.

17 J.T. Volkmar, Reisen nach dem Riesengebürge, Bunzlau 1777, s. 85-86: „Man heist sie die Drey-Steine, weil sie in der ferne nur als drey abgesonderte Felsen scheinen. Allein folgen sie mir bis zu ihrem Orte, sie werden sie sehenswürdig und in der grösten Menge finden. Hier steht erstlich eine Wand in einer halben Cirkulrunde, deren erstaunliche Felsklumpen so gleiche aufeinander gesetzt sind, als wenn sie die Baukunst gemessen, und nach Regeln aufgethürmt, oder besser, als wenn die Baukunst hier in der Schule gewesen wäre, und Muster davon genommen und ihre Regeln darnach eingerichtet hätte. Welche erstauende Höhe! Welche Art überspringender Steingesümse! Welche Figuren, die wie Thürme drüber hinaussteigen, und Blumentöpfe und andre Bauzierraten vorstellen! Und wer will alles beschreiben, bey einer vielfachen Menge der Steine an jeder Wand, von mehr als 100 Schritten in der Länge?”. W zaprezentowanym tu przekładzie pozwolono sobie na drobną zmianę: niemieckie pojęcie „Baukunst” (,sztuka budowlana” = „architektura”) zastąpiono osobą architekta, bardziej odpowiednią ze względów stylistycznych; dla łatwiejszego zrozumienia tekstu zdecydowano się też rozbić długie zdania niemieckie na kilka krótszych polskich odpowiedników. Jednakże w naszym przekonaniu do- 


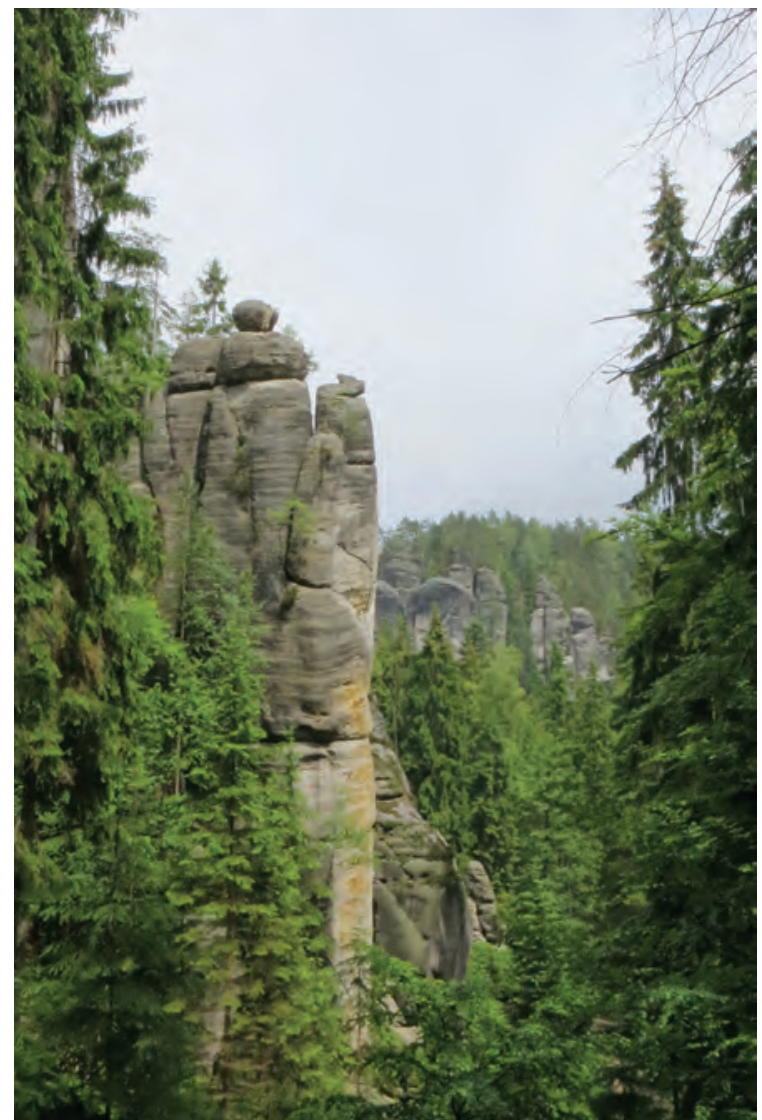

3. Adršpašské skalní město w czeskiej części Gór Stołowych, fot. Jan Pacholski (czerwiec 2015)

Podobnym tropem podąża znany nam już berlińczyk Jakob Elias Troschel. Zwiedzając słynne skalne miasto nieopodal czeskiego Adršpachu, przyrównuje je do antycznych ruin. Co więcej, zaczynając swój opis, duchowny ze stolicy nie odwołuje się do wrażenia, jakie wywiera na nim sama obserwacja obiektu, lecz wychodzi od opublikowanej relacji pochodzącej od osoby trzeciej, wzbogaconej jeszcze dołączonym do niej materiałem ikonograficznym:

Widok ten jest nader dziwny. Pan Otto z Berlina w czwartej części swych rozmaitych przyczynków do fizycznego opisu Ziemi, zawartych w publikacji Langhansa z 1739 roku, dostarczył szeregu informacji na ten temat i kopię wcale udanego miedziorytu przedstawiającego te okolice. $\mathrm{Z}$ oddali wygląda to jak ruiny P a $1 \mathrm{~m}$ iry czy P e r s e polis [wyr. oryg.],

konane w tłumaczeniu modyfikacje nie przeinaczają ogólnego wydźwięku zacytowanego passusu, co można łatwo sprawdzić, konfrontując przekład z zamieszczonym tu fragmentem oryginału. 
tylko szersze, wyższe, niż gdyby były to kolumny jakiejś świątyni czy miasta $^{18}$.

Ten fragment dobitnie ukazuje, w jak wielkim stopniu oświeceniowi podróżopisarze byli przywiązani do kultury, z której się wywodzili, w której tkwili zakorzenieni tak mocno, że nie byli w stanie pozbyć się jej gorsetu podczas podejmowania prób opisu natury.

Bliższy tej ostatniej był z pewnością niejaki Franz Fuß, zatrudniony jako zarządca („,dyrektor ekonomiczny”) dóbr rezydującego we Vrchlabí hrabiego Morzina, położonych w czeskich Karkonoszach. Ten przyrodoznawca amator opublikował w 1788 roku w Dreźnie pracę zatytułowaną Versuch einer Topographischen Beschreibung des Riesengebirges, mit Physikalischen Anmerkungen [Próba topograficznego opisu Karkonoszy, wraz z uwagami fizykalnymi], którą można traktować jako czeską odpowiedź na przytoczone wcześniej dzieło Slązaka — Volkmara; dla porządku dodajmy, iż obaj autorzy posługiwali się oczywiście językiem niemieckim. Jednak także Fuß w kilku miejscach swego dzieła wprost odnosi się do Hallera ${ }^{19}$, cytując lub parafrazując fragmenty utworów słynnego berneńczyka. Autor Alp nie jest jednakże jedynym Szwajcarem, do którego odwołuje się hrabiowski „dyrektor” z podkarkonoskiego miasteczka nad Łabą. W jednym miejscu swej publikacji porównał on góry wznoszące się na granicy między Czechami a Śląskiem - zagarniętym teraz przez wrogo nastawione Prusy! — do umocnień:

Tu znajdują się łańcuchy gór, ustawione niczym dzieła forteczne; załamane pod ostrym kątem fragmenty jednego pasma wpychają się we wklęsłe miejsca przeciwległego; szczególnie dwie ogromne góry, Žalý i Černá hora, wyglądają jak wysunięte elementy twierdzy, za którymi oczyma wyobraźni dostrzec można kształty dalszych umocnieńn ${ }^{20}$.

Ukazanie Karkonoszy jako potężnej naturalnej fortecy zdaje się mieć źródło we wspomnianym wcześniej słynnym dziele Johanna Jacoba Scheuchzera Histo-

18 J.E. Troschel, Reise von Berlin über Breslau nach dem schlesischen Gebirge im Sommer 1783, Berlin 1784, s. 94-95: „Der Anblik ist seltsam. Herr Otto in Berlin hat im 4ten Theil seiner vermischten Beiträge zur physikalischen Erdbeschreibung aus Langhans Beschreibung von 1739 einige Nachricht und einen Nachstich des wohlgetroffenen guten Kupferstichs davon geliefert. In der Ferne siehts wie Ruinen von Palmyra oder Persepolis aus, nur von grösserer Breite und Höhe, und dichter bey einander, als daß es Säulen eines Tempels oder einer Stadt seyn könnten".

19 Por. F. Fuss, Versuch einer Topographischen Beschreibung des Riesengebirges, mit Physikalischen Anmerkungen, Dresden 1788, s. 22, 33-34, 49.

${ }^{20}$ Ibidem, s. 14-15: „Hier finden sich Ketten von Bergen, die wie Festungswerke geordnet sind; die vorspringenden Winkel der einen Kette, stoßen auf die einwärts gehenden Winkel der entgegen gesetzten; besonders stellen die 2 ungeheuren Berge, der Heidelberg und der Schwarzberg, eine Art von Außenwerken vor, hinter welchen andere Gestalten von Festungswerken der Einbildungskraft sich darstellen". 
ria naturalna Helwecji ${ }^{21}$, którego autor przyrównuje okalające Szwajcarię góry do naturalnej twierdzy, dzięki której mieszkańcy tej krainy mogli w dawnych wiekach skutecznie bronić się przed najeźdźcami. W kontekście nowej sytuacji politycznej i dokonanego przez Prusy oderwania Śląska od pozostałych krajów Korony Królestwa Czech dawna granica przebiegająca przez Karkonosze i Góry Izerskie nabrała na znaczeniu, przestając być jedynie lokalną miedzą rozdzielającą dwie krainy pozostające pod władaniem jednego monarchy - czeskiego króla, a tym samym cesarza. W czasie gdy na terenie Czech powstawały nowe twierdze w Josefovie i Terezínie, kiedy rozbudowywano umocnienia Hradca Králové i morawskiego Ołomuńca, taki sposób postrzegania granicznych gór wydaje się jak najbardziej zrozumiały.

Zamykając niniejsze rozważania rodzajem klamry, pozostaje skonstatować, że tego rodzaju helweckie konotacje wcale nie były domeną jedynie pisarzy działających na południe od głównego grzbietu Sudetów. O „wspaniałej, szwajcarskiej okolicy" 22 pisze przecież Jakob Elias Troschel, otwierając swoją relację z podróży po Śląsku. Jeszcze dobitniej ujmuje to w przedmowie do swego wzorowanego na Alpach Hallera ${ }^{23}$ poematu Versuch eines Gedichtes über das Schlesische Riesen-Gebürge [Próba wiersza o Śląskich Karkonoszach] wrocławski lekarz Balthasar Ludwig Tralles, który nie bez pewnej dozy egzaltacji określa najwyższe góry swej ojczyzny mianem „naszych Śląskich Alp”24, zapewniając jednocześnie czytelnika solennie, iż podczas swojej pamiętnej karkonoskiej wędrówki ${ }^{25}$ miał przy sobie wydanie najsłynniejszego poematu berneńczyka, które wzruszyło go i zachwyciło niewymownie ${ }^{26}$.

\section{Bibliografia}

Buquoi E.F., Beschreibung meiner Reise durch einen Theil des schlesischen Gebirge, in etlichen Briefen an den Herrn Insp. Woltersdorff [dodatek do „Bunzlauische Monathschrift” = „Bunzlauische Monathschrift zum Nutzen und Vergnügen" 10, 1783].

Fuss F., Versuch einer Topographischen Beschreibung des Riesengebirges, mit Physikalischen Anmerkungen, Dresden 1788.

[GutsMuths J.Ch.F.], Meine Reise im deutschen Vaterlande, aus Thüringen ins Riesengebürge zu den Elbquellen und durch Böhmen ins Erzgebürge; über Erfurt, Leipzig, Dresden, Bautzen,

${ }^{21}$ Por. J.J. Scheuchzer, Helvetice Historia Naturalis Oder Natur-Historie Des Schweitzerlandes, Zürich 1716, s. 147-148.

22 J.E. Troschel, op. cit., s. 1: „Eine so herrliche, schweizerische Gegend”. Z przyczyn oczywistych w przytoczonym tu tłumaczeniu pojawia się przypadek zależny.

${ }^{23}$ I jemu też dedykowanego.

24 B.L. Tralles, Versuch eines Gedichtes über das Schlesische Riesen-Gebürge, Breslau-Leipzig 1750, niepaginowany ark. 6r: „unserer Schlesischen Alpen”.

25 Ową wędrówkę Tralles odbył przypuszczalnie w towarzystwie przedstawionego już Volkmara; por. L. Hillebrand, Das Riesengebirge in der deutschen Dichtung, Breslau 1922, s. 33.

26 Por. B.L. Tralles, op. cit., niepaginowany ark. $6^{\mathrm{r}}$. 
Görlitz, Bunzlau, Warmbrunn, Hirschberg, Arnau, Turnau, Prag und Töplitz bis Freyberg, Breslau-Hirschberg-Lissa in Südpreußen 1799.

Haller A. von, Die Alpen, [w:] idem, Versuch Schweizerischer Gedichte, b.m.w. [Bern] 1732, s. 1-25.

Haller A. von, Die Alpen (1729), [w:] idem, Versuch Schweizerischer Gedichte, Göttingen 1748, s. 29-52.

Haller A. von, Die Alpen (1729), [w:] idem, Gedichte, red. L. Hirzel, Frauenfeld 1882 („Bibliothek älterer Schriftwerke der deutschen Schweiz und ihres Grenzgebietes”, red. J. Bæchtold, F.. Vetter, t. 3), s. 20-42.

Hillebrand L., Das Riesengebirge in der deutschen Dichtung, Breslau 1922.

Hirzel L., Hallers Leben und Dichtungen, [w:] A. von Haller, Gedichte, red. L. Hirzel, Frauenfeld 1882, s. III-DXXXVI.

Pacholski J., Auf GutsMuths’ Spuren im Riesengebirge — fast eine Wanderung, „Silesia Nova” 3-4, 2013, s. 178-218.

Pacholski J., Wie das Riesengebirge gesehen wurde oder einige Bemerkungen zur sprachlichen Gestaltung der schlesischen Reiseberichte des ausgehenden 18. Jahrhunderts. Mit einem Exkurs zum literarischen Bild der Schneekoppe, [w:] Kontroversen in der heutigen germanistischen Linguistik: Ansichten, Modelle, Theorien, red. E. Błachut, A. Gołębiowski, Wrocław-Dresden 2015 (= „Beiträge zur allgemeinen und vergleichenden Sprachwissenschaft”, red. E. Błachut, A. Gołębiowski, t. 4), s. 7-30.

Scheuchzer J.J., Helvetice Historia Naturalis Oder Natur-Historie Des Schweitzerlandes, b.m.d.w. [Zürich 1716].

Tralles B.L., Versuch eines Gedichtes über das Schlesische Riesen-Gebürge, Breslau-Leipzig 1750. $\mathrm{T}$ [roschel] J.E., Reise von Berlin über Breslau nach dem schlesischen Gebirge im Sommer 1783 [von J.E.T.], Berlin 1784.

Ulrich J.H.F., Bemerkungen eines Reisenden durch die königlichen preußischen Staaten in Briefen, cz. 3, Altenburg 1781.

Volkmar J.T., Reisen nach dem Riesengebürge, Bunzlau 1777; pierwodruk: Beruhigungen des Herzens bey äuserlichen Weltunruhen durch allerley nützliche und gottselige Betrachtungen, Hirschberg 1760. 